\title{
Summit urged to clean up farming
}

\section{Leading scientists say that agriculture is a 'poor relation' in global-warming negotiations.}

\section{BY NATASHA GILBERT}

$\mathrm{D}$ elegates meeting this month in Durban, South Africa, to assess international progress on tackling climate change need to look beyond smoke stacks and car exhausts to a neglected source of emissions - agriculture.

That's the message from an international group of leading agricultural and climate scientists in a report published on 16 November. They say that agriculture is the "single largest contributor to greenhouse-gas pollution on the planet", through routes such as deforestation, rice growing and animal husbandry (see 'Farming footprint'). Emissions include nitrous oxide from fertilizer and methane from livestock, as well as carbon dioxide. With global food demand projected to double by 2050 , agriculture's emissions will grow - unless farming can become dramatically more efficient. Agriculture is a "poor relation" in negotiations on strategies to mitigate climate change, says John Beddington, Britain's chief scientific adviser and chair of the Commission on Sustainable Agriculture and Climate Change, an initiative of the Consultative Group on International Agricultural Research in Washington DC, which produced the report.

The United Nations Framework Convention on Climate Change (UNFCCC), sponsor of the Durban meeting, has no specific provisions for addressing agricultural greenhouse-gas emissions. The scientists recommend that parties to the UNFCCC establish a programme to develop a global sustainable agriculture strategy, and argue that the problem deserves a larger share of international climate-change mitigation funding.

"Everyone is hoping that UNFCCC will agree to establish the agricultural work programme in Durban. If it doesn't happen we will be in a much worse position," says Tim Benton, a sustainable-agriculture researcher at the University of Leeds, UK.

One author of the report, Tekalign Mamo, Ethiopia's minister of state for agriculture and rural development, told Nature that policy-makers at Durban should take examples of good

\section{DNATURE.COM}

Can science feed the world?

For more see: www.nature.com/food

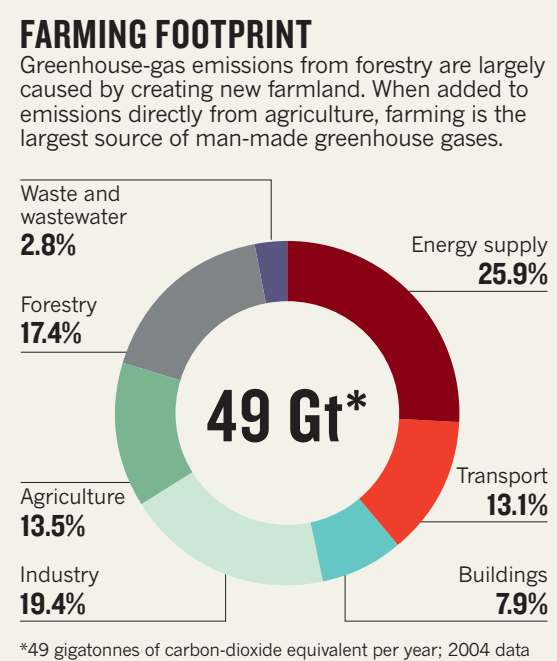

agricultural practice and replicate their success internationally. A successful programme in Ethiopia, for example, has given cash and food to poor households in exchange for labour on projects to improve soil quality, water supplies and infrastructure.

The report also praises Australia's Carbon Farming Initiative - the world's first national legislation aimed at reducing carbon emissions from farming and forestry, which was enacted in August. The law allows farmers and investors to generate and trade carbon credits from farming and forestry projects, and could serve as a model for similar projects in other countries.

Reducing waste is a key goal: one-third of the food produced for human consumption is lost to inefficiencies in production, storage and transport, the report says.

Benton believes that the "intellectual weight" of the report's authors will help it to influence policy-makers. As well as Beddington and Mamo, they include Carlos Nobre, a climate scientist at Brazil's National Institute for Space Research in São Paulo, and Marion Guillou, president of the French National Institute for Agriculture in Paris.

Camilla Toulmin, director of the International Institute for the Environment and Development in London, hopes Benton is right. But she worries that the prospects for decisive action at Durban are poor, because governments are "distracted by the economic crisis". - 


\section{CLARIFICATION}

The News story 'Summit urged to clean up farming' (Nature 479, 279; 2011) relied on a draft report supplied by the Commission on Sustainable Agriculture and Climate Change that stated that agriculture is the "single largest contributor to greenhousegas pollution". The final version of report states that agriculture is "a significant contributor to greenhouse gas emissions". 